\title{
ПРОБЛЕМИ ДЕРЖАВНОЇ КАДРОВОЇ ПОЛІТИКИ ТА ПЕРСПЕКТИВИ ЇХ ВИРІШЕННЯ НА РЕГІОНАЛЬНОМУ ТА МУНЦЦИПАЛЬНОМУ РІВНЯХ В УКРАЇНІ
}

Aндріяш B.I., д-р наук з держ. упр., професор, Інститут державного управління, Чорноморський національний університет імені Петра Могили м. Миколаїв, Україна

Свтушенко О.Н., д-р політ. наук, професор, Інститут державного управління, Чорноморський національний університет імені Петра Могили м. Миколаїв, Україна

Гончар C.B., канд. наук 3 держ. упр., Начальник служби повітряної вогневої, тактичної підготовки м. Одеса, Україна

У статті проаналізовано особливості стану сучасної державної кадрової політики на регіональному та муніципальному рівнях в Україні, щзо представляє собою особливу систему офічійно визнаних ичілей, завдань, пріоритетів й принцииів щзодо організації та регулювання кадрових процесів і взаємовідносин. Відзначено, щуо без розуміння особливостей державної кадрової політики як соиіального інституту, практично неможливо належним чином забезпечити найважливіші конституційне право службовців на роботу і професійно-кваліфікаційний розвиток. Розглянуто передумови формування нової парадигми державної кадрової політики, як сочіального інституту, орієнтованого на демократичний розвиток українського суспільства відповідно до вибраного курсу євроінтеграчії. Встановлено, щуо державна кадрова політика поступово перетворюється не в інструмент боротьби за владу, і ї̈ зміст, а на громадський ресурс публічного управління країною. Визначено особливості реалізації державної кадрової політики на регіональному та муніципальному рівні, які в умовах дещентралізації є провідними рівнями державної політи- 
ки розвитку країни. На сучасному етапі розвитку кадрового потенціалу краӥни кадрова політика повинна бути складовою сочіально-економічного розвитку регіону, громади і передбачати вдосконалення кадрової роботи на регіональному та муніципальному рівнях.

Ключові слова: державна кадрова політика, регіональний рівень, муніципальний рівень, кадрова робота.

Постановка проблеми у загальному вигляді. Після Революції гідності (2014р.) в державі стали домінувати кадрові процеси, характерні для перехідних періодів, які мають непередбачуваний, нелінійний характер, оскільки формування кадрового корпусу на центральному, регіональному та муніципальному рівнях стало залежати від уподобань політичних сил, що прийшли до влади.

Головна мета сучасної державної кадрової політики - забезпечити високий професіоналізм управлінського процесу кваліфікованими, активно діючими, добросовісними службовцями, здатними забезпечити відродження України $[14,60]$. В цілому кадрова політика стала характеризуватися високою змінюваністю і плинністю кадрів, а наявність корупції та переважання політичних, а не ділових підходів під час прийому на державну службу та і1ї проходження породило тенденцію кадрових призначень в регіонах, що залежить від волі посадових осіб органів державної влади, що діють часто не дотримуючись норм закону.

Аналіз досліджень і публікацій. Розглядаючи стан наукової розробки питання щодо кадрової політики загалом та реалізації реформи децентралізації зокрема, варто зазначити, що у сучасних наукових колах дослідників цієї галузі небагато, але чітко простежується тенденція підвищення інтересу до цієї проблематики таких учених, як Т. Теличко, М. Денисенко, О. Бюдякова, Т. Кахановська, В. Мамонової, Л. Пашко та інших. Дослідження проблем у межах теми грунтуються також на сучасних теоретико-методологічних розробках наступних дослідників: Г. Атаманчук, В. Коновалової, М. Ушакової та ін.

Метою статті є проаналізувати проблемні питання державної кадрової політики на регіональному та муніципальному рівнях. 
Формулювання цілей статті (постановка завдання). В процесі дослідження були поставлені наступні завдання:

- розглянути особливості функціонування кадрової державної політики;

- проаналізувати основні характеристики кадрової політики на регіональному та муніципальному рівнях;

- визначити особливості функціонування державної кадрової політики в умовах реформування;

- окреслити перспективи розвитку державної кадрової політики на регіональному та муніципальному рівнях.

Виклад основного матеріалу дослідження. Зміна політичної ситуації (втрата Криму, війна на Донбасі) не змінило курс держави, що знайшло своє відображення в ряді реформ, спрямованих на перебудову організаційно-адміністративної структури органів державної влади (далі - ОДВ) і органів місцевого самоврядування (далі - ОМС). У цих умовах державна кадрова політика (далі - ДКП) - це можливість перебудови системи публічного управління, складовою частиною якої $€$ система місцевого самоврядування. Система місцевого самоврядування - це «сукупність інститутів, взаємозв'язків між ними, а також людські, правові, матеріальні та фінансові ресурси, необхідні для вирішення місцевих питань» [9, с. 342]. Важливо підкреслити, що людські ресурси - сукупність «здатних до праці людей, складають основу системи місцевого самоврядування, оскільки об'єктом впливу ДКП на рівні держави $є$, всі людські ресурси (кадровий потенціал суспільства)», то на рівні муніципального утворення - це «кадровий потенціал відповідної адміністративно-територіальної одиниці» [5, с. 11].

У нових умовах розвитку української держави на порядку денному постало завдання формування ефективного кадрового потенціалу на регіональному та муніципальному рівні, за допомогою якого вдасться забезпечити проведення реформ, а в кінцевому підсумку буде сприяти соціально-економічному розвитку країни.

Тому головне завдання ДКП на зазначених рівнях - це забезпечення органів влади професійними і компетентними службовцями, здатними вирішувати завдання щодо досягнення поточних і перспективних цілей в інтересах суспільства, регіону [11, с. 8]. 
Реформа децентралізації, що розпочалася в 2014 році, в першу чергу стосувалася створення нової системи місцевого управління на рівні регіону і територіальної громади. На території 27 регіонів, що розташовані переважно в межах наявних областей (крім Києва і Севастополя), планувалося створити 120-150 районів, які будуть включати 1,5-1,8 тис. об'єднаних територіальних громад (далі - ОТГ), що дозволить збільшити фінансові можливості місцевих бюджетів [4, c. 86-87].

Дійсно, в період з 2014 по 2016 роки бюджети ОТГ збільшилися більш ніж на 100 млрд. грн. Також почала розвиватися власна інфраструктура ОТГ, на кошти інфраструктурної субвенції. Зокрема, новостворені ОТГ в 2016 р. реалізували 1383 проектів розвитку власної інфраструктури на суму понад 1 млрд. грн., а за 2016-2018 pp. реалізували 6380 таких проектів.

Можна констатувати, що власні доходи місцевих бюджетів в першому півріччі 2017 . виросли на 22 млрд. грн., це $+34 \%$ в порівнянні з аналогічним періодом минулого року і склали 87 млрд. грн. Вперше в Україні громади стають фінансово самодостатніми. Крім того, згідно $з$ прийнятою урядом бюджетною резолюцією процес щодо збільшення бюджетів місцевих громад буде тривати й надалі. Так, якщо на 2017 р. закладено 170 млрд. грн. доходів місцевих бюджетів, то на 2018 р. - 248 млрд. грн., на 2019 р. - 270 млрд. грн., на 2020 р. - 284 млрд. грн. Так, надходження власних доходів місцевих бюджетів України, за січень 2018 р. виросли на 2,9 млрд. грн. (+23,3\%) у порівнянні з аналогічним періодом 2017 р. і склали 15,4 млрд. грн.

Частка місцевих бюджетів 876 ОТГ в зведеному бюджеті України в 2018 р. перевищила 51 \%. Результати децентралізації вказують на те, що відбулися зміни у взаєминах між центром і ОМС, які отримали принципово нові функції і можливості, що спричинило за собою значне ускладнення і розширення поля діяльності посадових осіб місцевого самоврядування (далі - ПОМС). Кількість, яких в Україні, згідно з даними Національного агентства 3 питань державної служби на 01.01.2016 р., в Україні - 83465 осіб, що стосується регіонів, тут їх кількість залежить від кількості населення (табл. 1). 
Кількість ПОМС в Україні (станом на 01.01.2016 р.) [3]

\begin{tabular}{|l|l|l|l|l|l|}
\hline $\begin{array}{c}\text { № } \\
\text { п/п }\end{array}$ & \multicolumn{1}{|c|}{ Області } & $\begin{array}{c}\text { Кількість } \\
\text { ПОМС }\end{array}$ & $\begin{array}{c}\text { № } \\
\text { п/п }\end{array}$ & \multicolumn{1}{|c|}{ Області } & $\begin{array}{c}\text { Кількість } \\
\text { ПОМС }\end{array}$ \\
\hline 1 & Вінницька & 3917 & 13 & Миколаївська & 2487 \\
\hline 2 & Волинська & 2552 & 14 & Одеська & 4829 \\
\hline 3 & $\begin{array}{l}\text { Дніпропетров- } \\
\text { ська }\end{array}$ & 6867 & 15 & Полтавська & 3915 \\
\hline 4 & Донецька & 4493 & 16 & Ровенська & 2484 \\
\hline 5 & Житомирська & 3416 & 17 & Сумська & 3253 \\
\hline 6 & Закарпатська & 2117 & 18 & Тернопільська & 2612 \\
\hline 7 & Запорізська & 3770 & 19 & Харьківська & 5367 \\
\hline 8 & $\begin{array}{l}\text { Івано-Франків- } \\
\text { ська }\end{array}$ & 3081 & 20 & Херсонська & 2461 \\
\hline 9 & Київська & 4352 & 21 & Хмельницька & 3128 \\
\hline 10 & Кіровоградська & 2734 & 22 & Черкаська & 3364 \\
\hline 11 & Луганська & 1679 & 23 & Чернівецька & 1688 \\
\hline 12 & Львівська & 5579 & 24 & Чернігівська & 3082 \\
\hline
\end{tabular}

Джерело: Складено авторами на основі даних збірки "Державна служба в иифрах 2015. Інформачійне видання. Національне агентство України з питань держсавної служби. Центр адаптації державної служби до стандартів Свропейського Союзу, Київ, 32 с.».

Наведені дані свідчать про достатній кадровий ресурс але, по-перше, кількісні показники не дозволяють робити висновки щодо професіоналізму й ефективності кадрового потенціалу, тим більше, що в ході реалізації реформи відзначається недолік професійних кадрів і компетенції управлінських команд, що займаються іiї реалізацією; по-друге, якщо кількісні показники представляються більшменш задовільними, то тільки на рівні міст, районів, областей, а не сільських і селищних територіальних громад, адже і сьогодні мало 
бажаючих фахівців їхати туди на роботу; по-третє, з моменту створення ОТГ і розширення їх функцій і можливостей, потреба в професійних кадрах тільки зростає (за даними Держслужби зайнятості потреба в кадрах для ОТГ на 01.09.2018 p. - 9 тис. вакансій), тому питання посилення кадрового потенціалу місцевого самоврядування в нових умовах стоїть дуже гостро; по-четверте, існує проблема плинності кадрів, як в органах державної влади, так і місцевого самоврядування, особливо на рівні територіальної громади (створення ОТГ, призводить до зменшення кількості сільських, селищних рад (на 01.01.2015 р. було - 84548 ПОМС, то на 01.01.2016 р. -83465 ПОМС); по-п'яте, не вирішена проблема навчання, підвищення кваліфікації або перекваліфікації ПОМС, що визнається як владою, так і самими державними службовцями і ПОМС.

Вказані проблеми характеризують відсутність в країні ефективної системи ДКП, під якою ми розуміємо стратегію довгострокового формування, розвитку та раціонального використання людських ресурсів держави. Тобто наявність в органах державної влади й місцевого самоврядування кадрів, що мають відповідні повноваження виконувати адміністративно-розпорядчі функції, готувати, приймати й реалізовувати управлінські рішення. Саме від якості та результативності роботи державних службовців і посадових осіб місцевого самоврядування залежить довіра населення до органів влади i самоврядування.

У той же час в процесі децентралізації, реформи місцевого самоврядування, створення ОТГ, а в подальшому виконавчих комітетів районних і обласних рад, які візьмуть на себе повноваження, що належали державним адміністраціям, кількість ПОМС почне збільшуватися і заповнити нестачу кадрів в ОМС частково можна за рахунок скорочених державних службовців.

Поступове скорочення державних службовців пов'язано, по-перше, з вимогою МВФ. Так, в меморандумі України з МВФ прописано скорочення працівників бюджетної сфери, зокрема в 2017 році не менше 4 \% і на 10 \% до кінця 2019 р. В цьому контексті підкреслимо, що скорочення чисельності державних службовців має відбуватися за необхідності, а не заради скорочення, тому 
скорочення державних службовців не повинні бути всеосяжними і шаблонними, адже такі дії фактично можуть привести до зниження ефективності роботи ОДВ. По-друге, скорочення пов'язано 3 появою нових вимог до професіоналізму і якості роботи державної служби, адже в ОДВ є багато чиновників в статусі державних службовців. Згідно із законом статус державних службовців втратять ті чиновники, які потрапляють на державну службу «не за конкурсом, а за політичними квотами (заступники міністрів, голова та члени Рахункової палати, члени ЦВК, глава РНБО), обслуговуючий персонал, (бібліотекарі, водіï), представники патронатної служби (прес-секретарі, помічники, радники), судді, працівники НБУ» [3]. За приблизними підрахунками кількість державних службовців скоротиться - на 30\% (зараз в Україні кількість державних службовців в системі органів виконавчої влади скоротилася приблизно 3 295709 чол. до 250000 чол.).

На муніципальному рівні в новоутворених ОТГ, спостерігається відсутність кваліфікованих професійних фахівців здатних ефективно і професійно виконувати надані їм повноваження, а «люди, котрих обрано, не завжди, на жаль, бачать, як саме правильно варто впроваджувати ті або інші проекти» [2, с. 39]. Створення ОТГ викликало потребу в навчанні великої кількості управлінців. Цю проблему можна було б вирішити за допомогою короткострокових курсів, однак вся надія на допомогу в цьому питанні СС, через створення центру дистанційної освіти.

Потреба ОМС, в кваліфікованих кадрах, які мають вищу освіту і здатних в сучасних умовах використовувати в роботі ефективні управлінські технології постійно зростає. За даними Національного агентства України з питань державної служби в ОМС повну вищу освіту мають - 62169 чол., що становить 74,5 \% до облікової кількості посадових осіб. 3 них ПОМС, які «займають керівні посади, повну вищу освіту мають - 27426 чол., що становить 74,2 \% до облікової кількості посадових осіб відповідної категорії» [3]. Неповну базову вищу освіту мають - 20540 чол., що складає 24,6 \% до загальної облікової кількості ПОМС відповідної категорії. Серед керівників неповну базову вищу освіту 
мають 9094 чол., що становить 24,6 \% до облікової кількості посадових осіб відповідної категорії. Зокрема, 161 посадова особа має науковий ступінь, переважна більшість серед них (136 осіб) керівники.

Серед фахівців, повну вищу освіту мають - 34743 чол., що складає 74,7 \% до облікової кількості ПОМС відповідної категорії. Крім того, «неповну базову вищу освіту серед фахівців мають 11446 чол., що становить 24,6 \% до облікової кількості посадових осіб відповідної категорії. Науковий ступінь серед фахівців - у 25 чол.» [3]. Щодо категорій посад, то серед керівників повну вищу освіту мають керівники, які відносяться до 5 категорії (14658 чол., 72,6 \%) і 4 категорії (8543 чол., 69,9 \%). Серед фахівців повну вищу освіту переважно мають фахівці 6 (19437 чол., 92,5 \%) і 7 (13549 чол., 57,6 \%) категорії.

Наявність такої кількості ПОМС з вищою освітою пов'язано 3 тим, що однією з основних вимог, що «висуваються до кандидатів на заміщення вакантних посад у місцевому самоврядуванні, $\epsilon$ обов'язкова наявність повної вищої (для керівників, головних спеціалістів), або неповної вищої освіти для фахівців 6 і 7 категорії» [3]. Наголосимо, що кількість ПОМС, котрі мають повну вищу освіту постійно зростає, що вважається позитивною характеристикою структури кадрів ОМС з точки зору професійної підготовки.

Щодо регіонального рівня, то наприклад, в Херсонській області повну вищу освіту мають 1851 чол., що становить 75,2 \% від кількості посадових осіб відповідної категорії. У Миколаївській області ПОМС 3 повною вищою освітою становлять 79,1 \% (1968 чол.). Неповну базову вищу освіту в Херсонській області мають - 578 чол., що становить 23,5 \% до облікової кількості ПОМС відповідної категорії. Зокрема, в Миколаївській області неповну базову вищу освіту мають 504 чол. (20,3%). Для порівняння візьмемо Одеську область, де і населення більше і ПОМС в «два рази більше, але відсоток осіб з повною вищою та неповною вищою освітою залишається приблизно на тому ж рівні» [3] (табл. 2). 
Таблиця 2

Кількість ПОМС за рівнем освіти (на 01.01.2016 р.) [3]

\begin{tabular}{|c|c|c|c|c|c|c|c|c|}
\hline \multicolumn{9}{|c|}{ Посадові особи, котрі мають: } \\
\hline & \multicolumn{2}{|c|}{ повну вищу освіту } & \multicolumn{2}{|c|}{$\begin{array}{c}\text { неповну, базову } \\
\text { вищу освіту }\end{array}$} & \multicolumn{2}{|c|}{$\begin{array}{c}\text { науковий } \\
\text { ступінь }\end{array}$} & \multicolumn{2}{|c|}{$\begin{array}{l}\text { вчений } \\
\text { ступінь }\end{array}$} \\
\hline & த் & 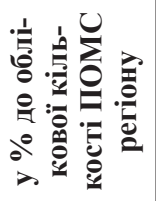 & ड் & 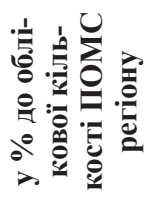 & $\dot{5}$ & 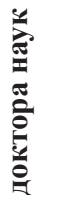 & $\dot{\vec{j}}$ & 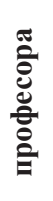 \\
\hline Миколаївська & 1968 & 79,1 & 504 & 20,3 & 1 & - & - & - \\
\hline Одеська & 3836 & 79,4 & 984 & 20,4 & 17 & 3 & 1 & - \\
\hline Херсонська & 1851 & 75,2 & 578 & 23,5 & 4 & 1 & - & - \\
\hline Україна & 62169 & 74,5 & 20540 & 24,6 & 161 & 25 & 20 & 6 \\
\hline
\end{tabular}

Дюерело: Складено авторами на основі даних збірки "Державна служба в иифрах 2015. Інформаційне видання. Національне агентство України з питань державної служби. Центр адаптації державної служби до стандартів Свропейського Союзу, Київ, 32 с.».

Показники не сильно відрізняються від всеукраїнських і вказують на досить високий рівень освіти державних службовців і ПОМС. Однак наявність вищої освіти не гарантує високий рівень професійної підготовки, і компетентності державних службовців і ПОМС. Слід підкреслити, що значна частина державних службовців і ПОМС на регіональному та муніципальному рівні не мають спеціальної освіти, що відповідає профілю їхньої професійної діяльності. Так, на 01.01.2015 р., професійну освіту за напрямом «Державне управління», «Місцеве самоврядування» серед 295709 державних службовців мали лише 9256 чол. (3,1 \%), а 384548 ПОМС професійну освіту мали лише 3038 чол. (3,5 \%).

Ситуація значно не покращилася і в наступному році. Так, на 01.01.2016 р. в Україні налічувалося 268370 державних службов- 
ців (підвищили кваліфікацію 47222 чол., тобто 17 \%.). Також на 01.01.2016 р. в Україні налічувалося 83465 ПОМС, а програмами підвищення кваліфікації протягом 2015 р. було охоплено лише 7476 ПОМС (2559 керівників і 3917 фахівців), що становить 9 \% від загальної чисельності ПОМС. Проблема компетентності (наявність знань і досвіду, необхідних для ефективної діяльності) ПОМС, стоїть дуже гостро. Особливо зараз, коли в результаті децентралізації, OMC, зокрема ОТГ (сільські та селищні територіальні громади, які становлять близько 91 \% від загальної кількості ОМС), отримали ряд нових повноважень, виконання яких вимагає значного обсягу додаткових знань і умінь. Відсутність достатнього рівня знань, освіти відзначають як керівники (79\% керівників ОТГ) так і фахівці місцевого самоврядування (77 \% секретарів і працівників виконавчих органів ОТГ і 70 \% старост). В ОТГ абсолютна більшість ПОМС (96-97 \%) визнають важливість навчання і підвищення кваліфікації.

Якісне кадрове забезпечення ОДВ і ОМС висококваліфікованими професіоналами, здатними якісно і ефективно реалізовувати на практиці управлінські функції, безпосередньо пов'язане з ефективною регіональною кадровою політикою. Сьогодні кожен регіон намагається самостійно вирішувати проблему підвищення професійних навичок ПОМС. До цієї роботи залучаються обласні центри перепідготовки та підвищення кваліфікації працівників ОДВ і OMC, в яких новообрані сільські, селищні, міські голови ОТГ мають можливість підвищувати свою професійну компетентність беручи участь в організованих для них семінарах. Ми вважаємо, що це один з напрямків професійного підвищення кадрового потенціалу ОДВ і місцевого самоврядування, тому що саме кадри, повинні стати активним суб'єктом забезпечення ефективності соціально-економічних, технологічних, соціально-психологічних процесів, які відбуваються в українському суспільстві. Ми також погоджуємося 3 дослідниками, які пропонують розробити «дорожню карту» державних службовців і службовців місцевого самоврядування, котра повинна отримати статус офіційного формалізованого документу. Така «дорожня карта» («журнал професійної освіти») повинна формуватися «одночасно з обранням кандидата на державну служ- 
бу або в ОМС і закінчуватися його виходом на пенсію» [12, с. 82].

Оцінюючи ситуацію, яка склалася 3 кадрами в ОДВ і ОМС розглянемо дані статистики, які характеризують вікову структуру ПОМС. Вікові характеристики до 35 років і вище взяті авторами для дослідження не випадково, оскільки саме у віці до 35 років ПОМС знаходяться на етапі становлення і розвитку своєї кар'єри, тобто відчувають потребу в самоствердженні й самовираженні. «Вони активно шукають шляхи підвищення ефективності своєї діяльності й роботи організацій та підрозділів, активно засвоюють нові знання. Працівники у віці від 35 до 45 років досить негативно ставляться до критичних зауважень, найменш сприйнятливі до порад. Вони «прихильно вислуховують рекомендації котрі досить часто їм не потрібні» [9, с. 318].

Так в таб. 3 показано розподіл ПОМС (жінок) за віком.

Таблиця 3

Розподіл ПОМС (жінок) за віком [3]

\begin{tabular}{|c|c|c|c|c|c|c|c|}
\hline & \multirow{2}{*}{$\begin{array}{c}\text { Кіль- } \\
\text { кість } \\
\text { жінок, } \\
\text { чол. }\end{array}$} & \multicolumn{6}{|c|}{$\begin{array}{c}3 \text { них у віці, років (у \% до загальної кількості } \\
\text { певного регіону) }\end{array}$} \\
\hline & & 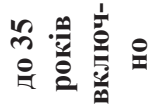 & $\begin{array}{l}n \\
0 \\
n\end{array}$ & 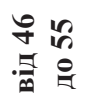 & 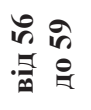 & $\begin{array}{ll}8 & 7 \\
0 & 0 \\
0 & 0\end{array}$ & $\begin{array}{l}0 \\
60\end{array}$ \\
\hline Миколаївська & 1995 & 28,4 & 29,0 & 34,8 & 6,3 & 1,5 & - \\
\hline Одеська & 3753 & 34,9 & 29,2 & 28,2 & 6,3 & 1,3 & \\
\hline Херсонська & 1918 & 25,6 & 29,5 & 35,9 & 7,3 & 1,5 & 0,2 \\
\hline Україна & 64338 & 28,3 & 32,0 & 32,8 & 5,8 & 1,0 & 0,1 \\
\hline
\end{tabular}

Джерело: Складено авторами на основі даних збірки «Державна служба в иифрах 2015. Інформаџійне видання. Національне агентство України з питань державної служби. Центр адаптачії державної служби до стандартів Свропейського Союзу, Київ, 32 с.».

Більшість ПОМС серед жінок у віці від 46 до 55 років (в Херсонській області їх більше у відсотках, ніж загалом по Україні), 
що свідчить про те, що при підборі співробітників в ОМС, перевага все ж віддається більш зрілим і досвідченим кандидатам, ніж молодим. Цей показник характеризує частку ПОМС (жінок), які працюють тривалий термін в ОМС.

На рис. 1 показано динаміку розподілу ПОМС (жінок) за віком.

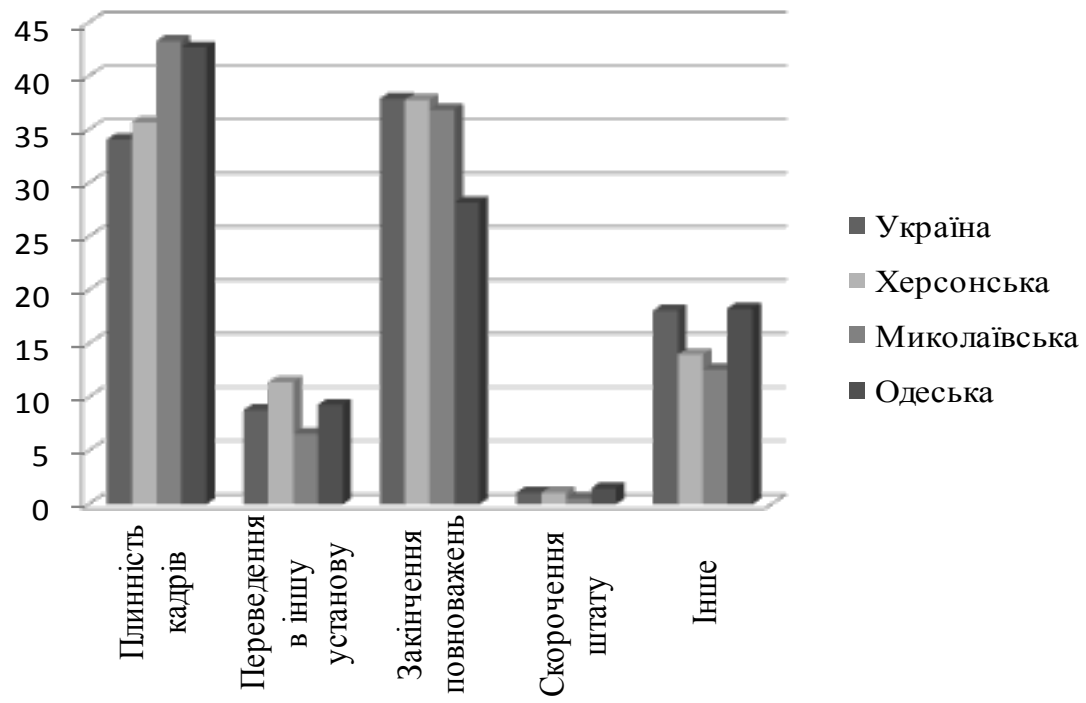

Рис. 1. Динамічність розподілу ПОМС (жінок) за віком

Джерело: Складено авторами на основі даних збірки "Державна служба в ичифрах 2015. Інформачійне видання. Національне агентство України з питань державної служби. Центр адаптації державної служби до стандартів Свропейського Союзу, Київ, 32 с.».

3 даних табл. 3 і табл. 4, рис. 1 і рис. 2 можна відзначити те, що кадровий склад за віком (до 45 років) досить молодий, а значить більш динамічний, і досвідчений. Це вік, коли ПОМС досягли певних успіхів у своїй кар'єрі. 
Розподіл ПОМС (чоловіків) за віком [3]

\begin{tabular}{|c|c|c|c|c|c|c|c|}
\hline & \multirow{2}{*}{ 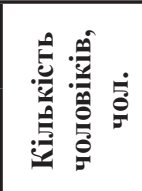 } & \multicolumn{6}{|c|}{$\begin{array}{c}3 \text { них у віці, років (у \% до загальної кількості } \\
\text { певного регіону) }\end{array}$} \\
\hline & & 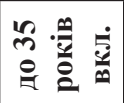 & 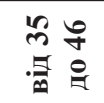 & 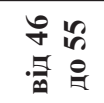 & 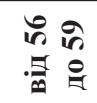 & 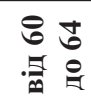 & 告兽 \\
\hline Миколаївська & 492 & 24,0 & 23,0 & 34,8 & 14,6 & 2,2 & 1,4 \\
\hline Одеська & 1076 & 27,0 & 24,6 & 28,0 & 16,5 & 2,3 & 1,6 \\
\hline Херсонська & 543 & 25,4 & 25,4 & 29,7 & 16,2 & 2,4 & 0,9 \\
\hline Україна & 19127 & 25,0 & 24,8 & 32,0 & 15,2 & 2,2 & 0,8 \\
\hline
\end{tabular}

Джкерело: Складено авторами на основі даних збірки «Державна служба в иифрах 2015. Інформаційне видання. Національне агентство України з питань державної служби. Центр адаптації державної служби до стандартів Свропейського Союзу, Киї, 32 с.».

Дані про вікову структуру ПОМС (чоловіків) свідчать, що середній вік співробітників становить 39 років, також спостерігається досить рівномірний розподіл часток ПОМС (чоловіків) за віковими категоріями, що є певним свідченням збалансованості кадрового складу за віковою ознакою серед ПОМС в Херсонській області.

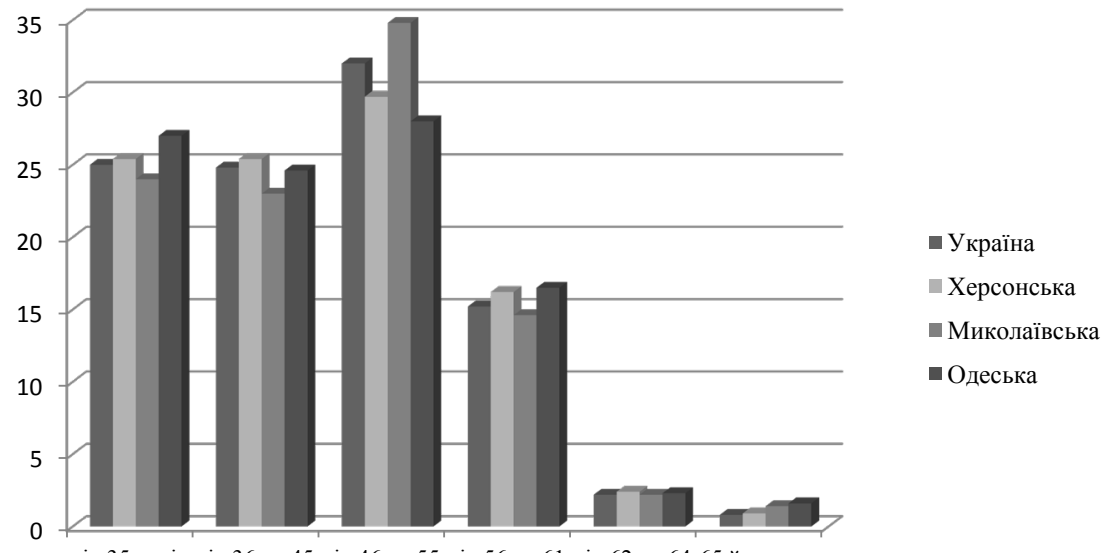

від 35 років від 36 до 45 від 46 до 55 від 56 до 61 від 62 до 6465 й старше

Рис. 2. Динамічність розподілу ПОМС (чоловіків) за віком 
Джерело: Складено авторами на основі даних збірки «Державна служба в иифрах 2015. Інформаційне видання. Національне агентство Украӥни з питань державної служби. Центр адаптачії державної служби до стандартів Свропейського Союзу, Київ, 32 с.».

Отже, наявні статистичні дані дозволяють зробити висновок, що в ОМС Херсонської області кадровий склад ПОМС складають службовці в найбільш продуктивному віці, що має позитивно позначитися на ефективності діяльності ОМС. Далі, перейдемо до аналізу розподілу ПОМС за стажем роботи в ОМС (табл. 5).

Таблиця 5

\section{Розподіл ПОМС за стажем роботи в ОМС [3]}

\begin{tabular}{|l|l|c|c|c|c|c|c|}
\hline \multirow{4}{*}{} & \multicolumn{6}{|c|}{$\begin{array}{c}\text { Кількість працівників, які мають стаж роботи, роки } \\
\text { (у\% до загальної кількості ПОМС регіону) }\end{array}$} \\
\cline { 2 - 8 } & $\begin{array}{c}\text { від 1 } \\
\text { року }\end{array}$ & $\begin{array}{c}\text { від 1 } \\
\text { до 3 }\end{array}$ & $\begin{array}{c}\text { від 3 } \\
\text { до 5 }\end{array}$ & $\begin{array}{c}\text { від 5 } \\
\text { до 10 }\end{array}$ & $\begin{array}{c}\text { від 10 } \\
\text { до 15 }\end{array}$ & $\begin{array}{c}\text { від 15 } \\
\text { до 25 }\end{array}$ & $\begin{array}{c}\text { більше } \\
\mathbf{2 5}\end{array}$ \\
\hline Миколаївська & 10,1 & 7,4 & 9,3 & 24,6 & 23,1 & 20,3 & 5,2 \\
\hline Одеська & 10,3 & 11,3 & 9,6 & 26,4 & 21,5 & 15,6 & 5,3 \\
\hline Херсонська & 11,1 & 8,9 & 8,2 & 24,5 & 25,2 & 18,0 & 4,1 \\
\hline Україна & 9,6 & 8,0 & 8,3 & 25,0 & 24,9 & 19,0 & 5,2 \\
\hline
\end{tabular}

Джерело: Складено авторами на основі даних збірки «Державна служба в цифрах 2015. Інформаційне видання. Національне агентство Украӥни з питань державної служби. Центр адаптачії державної служби до стандартів Свропейського Союзу, Київ, 32 с.».

Аналізуючи показники табл. 5 видно, що у більшості ПОМС професійний стаж становить від 5 до 15 років. Якщо взяти до уваги дані $з$ табл. 2, а точніше дані щодо освітнього рівня, то можемо зробити висновок, що в ОМС Херсонської області працюють освічені, зрілі працівники, котрі мають достатній досвід роботи.

$\mathrm{У}$ той же час розподіл ПОМС за стажем в ОМС в розрізі категорій посад, що відображає природний процес розвитку посадових 
кар'єр в ОМС свідчить: підвищення на посаді відбувається зі збільшенням стажу і досвіду роботи.

На ефективність і результативність ОДВ і ОМС істотно впливає плинність кадрів, оскільки перешкоджає становленню професіоналізму державних службовців і ПОМС. Розглянемо характерні показники плинності ПОМС, наприклад, кількість працівників, які вибули з ОМС, за категоріями посад в 2014 році. По Україні це складає - 15658 чол., що становить 18,8 \% від загальної кількості ПОМС відповідної категорії. У Херсонській області вибули з ОМС - 526 чол., що становить 24,1% (табл. 6).

Таблиця 6

\section{Кількість ПОМС, які вибули 3 органів місцевого самоврядування [3]}

\begin{tabular}{|c|c|c|c|c|c|c|c|}
\hline & \multicolumn{2}{|l|}{ Вибули } & \multicolumn{5}{|c|}{ В тому числі по причині, \% } \\
\hline & 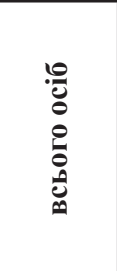 & 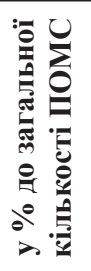 & 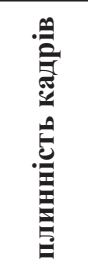 & 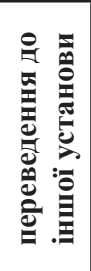 & 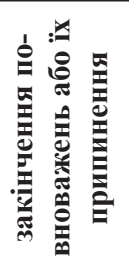 & 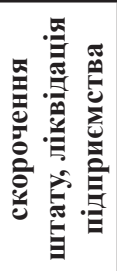 & 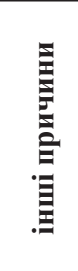 \\
\hline Миколаївська & 515 & 20,7 & 43,3 & 6,6 & 36,9 & 0,6 & 12,6 \\
\hline Одеська & 927 & 19,2 & 42,7 & 9,3 & 28,2 & 1,5 & 18,3 \\
\hline Херсонська & 526 & 21,4 & 35,7 & 11,4 & 37,8 & 1,1 & 14,0 \\
\hline Україна & 15658 & 18,8 & 34,1 & 8,8 & 37,9 & 1,1 & 18,1 \\
\hline
\end{tabular}

Джерело: Складено авторами на основі даних збірки «Державна служба в цифрах 2015. Інформаційне видання. Національне агентство України з питань державної служби. Центр адаптачії державної служби до стандартів Свропейського Союзу, Київ, 32 с.».

Більшість звільнених у зв'язку із закінченням повноважень або ïх дострокового припинення - 37,8 \% (в першу чергу це стосується виборних посад, тобто закінчився термін повноважень). На другому 
місці плинність кадрів - 35,7 \% (табл. 6, рис. 3), тобто звільнених за власним бажанням, з ініціативи керівництва, в зв'язку з переходом в комерційні структури, або з можливістю отримувати більш високу оплату праці. Плинність кадрів - це ключова проблема як для ОДВ, так й для ОМС. Плинність кадрів може бути розрахована за допомогою формули:

$\mathrm{F}=$ Зв.ср.г. * 100 / Ч ср.г. (1)

де Зв.ср.г. - середньорічна чисельність звільнених,

Ч ср.г. - середньорічна чисельність.

$\mathrm{F}$ - рівень плинності кадрів (співвідношення числа звільнених працівників, які вибули за певний період (рік) до середньої врахованої чисельності за той же період х 100\%).

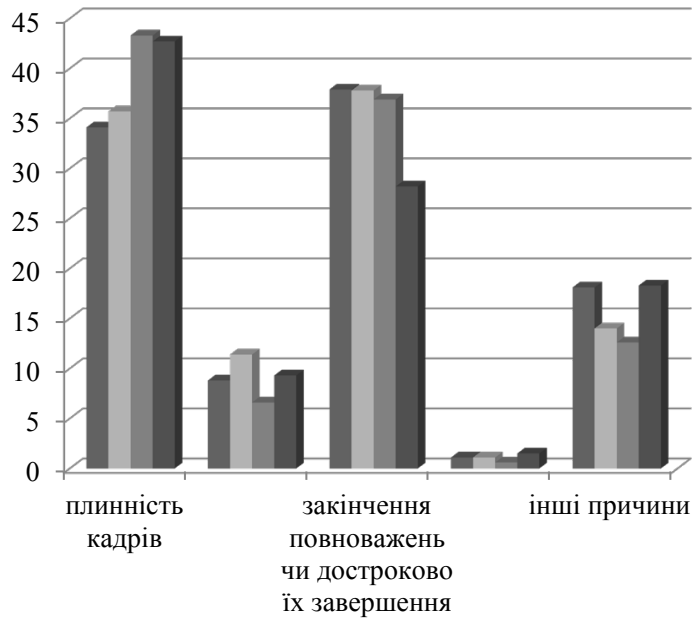

$$
\begin{aligned}
& \text { — Україна } \\
& \text { Херсонська } \\
& \text { - Миколаївська } \\
& \text { - Одеська }
\end{aligned}
$$

Pис. 3. Динаміка кількості ПОМС, котрі вибули із ОМС

Джерело: Складено авторами на основі даних збірки «Державна служба в ичифрах 2015. Інформаційне видання. Національне агентство України з питань державної служби. Центр адаптації державної служби до стандартів Свропейського Союзу, Київ, 32 с.».

Варто зауважити, що рівень «нормальної» плинності в установі має дорівнювати 3-5 \%, оскільки вказана величина відповідає при- 
родному відновленню персоналу. Стурбованість викликає, якщо рівень плинності перевищує 15 \%, тобто перевищує норму (10-12\%), що не $\epsilon$ нормальним, керівництво повинно вживати заходів, щоб знизити дане значення. По-перше, «зайва плинність викликає значні економічні втрати, а по-друге, створює організаційні, кадрові, технологічні, психологічні труднощі» [3].

Зазначені показники характеризують роботу кадрових служб місцевого самоврядування [8, с. 64]. Їх робота в основному зводиться до оформлення трудових взаємовідносин з працівниками структурних підрозділів ОМС, не використовуючи такі форми діяльності, як робота 3 метою створення згуртованого, професійного, відповідального колективу для реалізації його функцій і завдань. Однак, якщо «діяльність кадрових служб розглядати як процес, то з точки зору цього підходу діяльність кадрових служб ОМС», як наголошує Г. Атаманчук - це «кадрове забезпечення організації» [2, с. 156].

У процесі дослідження було проведено опитування серед 352 службовців ОМС Миколаєва та Миколаївської області, звільнених у 2015-2017 роках (рис. 4). Мета опитування виявити основні мотиви звільнення співробітників.

Як видно з результатів опитування найбільш вагомою причиною звільнення ПОМС є низька заробітна плата, точніше недосконалість оплати праці ПОМС, відсутність чітких кар'єрних перспектив і конфлікти 3 керівництвом. Слід підкреслити, що на урядовому рівні України стурбовані комплектуванням ОМС фахівцями з відповідним рівнем освіти, кваліфікації та (за потребою) стажу роботи за даною спеціальністю. У 2018 р. згідно з Постановою КМУ від 10.05.2018 р. № 363 встановлено нові вищі посадові оклади для ПОМС. Всі інші причини (перспективи кар'єрного росту і конфлікти) цілком можуть бути вирішені кадровими службами і керівництвом ОМС [1]. Однак їх наявність характеризує відсутність в роботі кадрових служб системної роботи з підбору, планування навчання та кар'єрного росту державних службовців і ПОМС. Адже основне завдання кадрової служби це не тільки ведення кадрової документації, це також і розміщення кадрів, їх атестація, підготовка, перепідготовка і підвищення кваліфікації; оформлення стажувань працівників. 


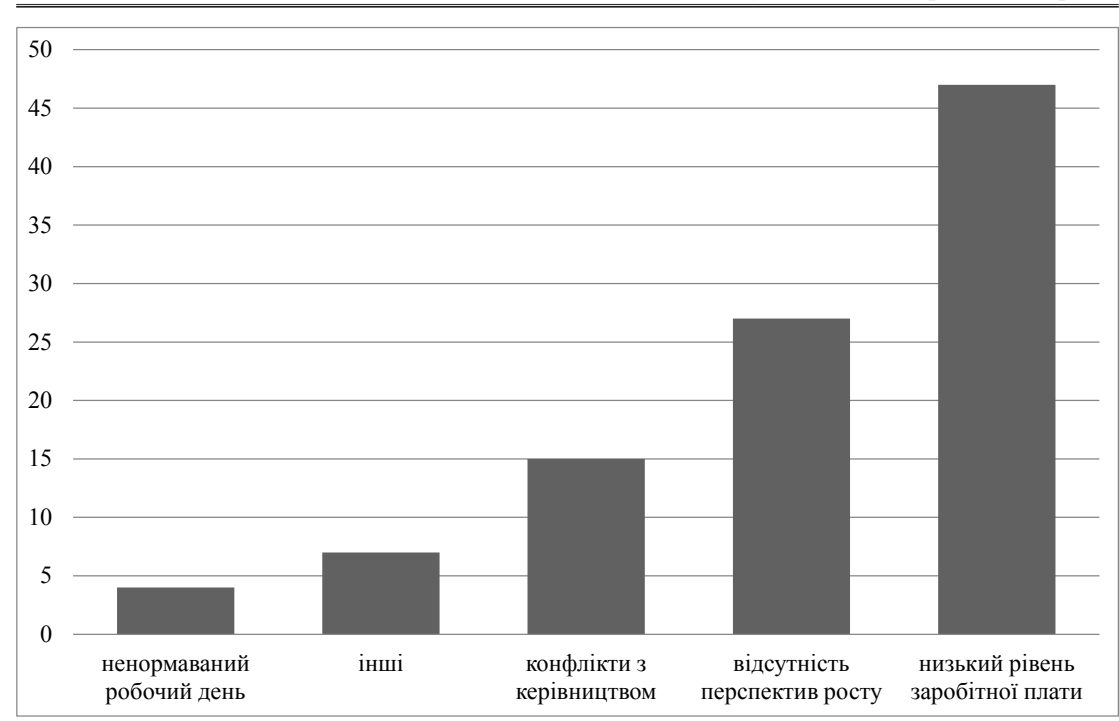

Pис. 4. Причини звільнення з ОМС

Джерело: Складено авторами на основі даних проведеного опитування серед колишніх службовиів ОМС за останні 3 роки.

Розгляд кадрового забезпечення ОМС в даному «контексті більш доцільно розглядати з позиції реалізації цілей і завдань місцевого самоврядування, в першу чергу - для досягнення поточних і перспективних цілей в інтересах місцевої громади, регіону і держави» [7, с. 220], тобто ефективності або неефективності роботи державних службовців і ДЛМС.

Для з'ясування причин неефективної діяльності державних службовців та ПОМС на регіональному та муніципальному рівнях авторами було проведено опитування 320 респондентів (за допомогою опитувальних листів, що самостійно заповнюються опитуваними за зазначеними у ньому правилам). Всі респонденти працюють на керівних посадах в органах державної влади та місцевого самоврядування (далі експерти) Миколаївської області.

Перед опитуваними було поставлено питання: у чому експерти бачать основні причини невисокої компетентності та неефективнос- 
ті дій сучасних державних службовців і ПОМС? Експертам було запропоновано для відповіді такі причини:

- недосконала нормативно-правова база кадрового забезпечення ДКП на субрегіональному і муніципальному рівнях;

- недостатність професійних знань і умінь задля роботи за умов євроінтеграції, демократизації та децентралізації державної влади;

- неясність сприйняття та розуміння державними службовцями й ПОМС власних й делегованих повноважень;

- відсутність в ОДВ і ОМС підготовлених професійних кадрів за спеціальністю «Державне управління» та «Місцеве самоврядування»;

- неефективна система відбору, розстановки, підвищення кваліфікації, кар'єрного росту, оцінки діяльності кадрів в ОДВ і ОМС.

Проведене авторами опитування експертів дав наступні результати (табл. 7).

Таблиця 7

\section{Причини низької компетентності та неефективності дій сучасних державних службовців і ПОМС [3]}

\begin{tabular}{|c|c|c|}
\hline $\begin{array}{l}\text { № } \\
\text { П\\
I }\end{array}$ & Зміст питання & 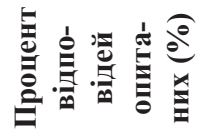 \\
\hline 1. & $\begin{array}{l}\text { Неефективна система відбору, розстановки, підвищення } \\
\text { кваліфікації, кар'єрного росту, оцінка діяльності кадрів в } \\
\text { ОДВ та ОМС }\end{array}$ & 40 \\
\hline 2. & $\begin{array}{l}\text { Недостатність професійних знань та вмінь для роботи в } \\
\text { умовах демократизації та децентралізації }\end{array}$ & 20 \\
\hline 3. & $\begin{array}{l}\text { Недосконала нормативно-правова база забезпечення ДКП } \\
\text { на регіональному та муніципальному рівнях }\end{array}$ & 15 \\
\hline 4. & $\begin{array}{l}\text { Відсутність в ОДВ та ОМС підготовлених професійних } \\
\text { кадрів }\end{array}$ & 15 \\
\hline 5. & $\begin{array}{l}\text { Неясне розуміння державними службовцями та ПОМС } \\
\text { кола власних повноважень }\end{array}$ & 10 \\
\hline
\end{tabular}

Джерело: Складено авторами на основі даних проведеного опитування серед колишніх службовців ОМС за останні 3 роки. 
Отримані результати свідчать, що причини, низького професіоналізму державних службовців і ПОМС полягають в неефективності системи відбору, розстановки, підвищення кваліфікації, кар'єрного росту, оцінки діяльності кадрів. Неефективність роботи 3 кадрами на регіональному та муніципальному рівнях - $є$ однією 3 головних причин негативного ставлення громадян до ОДВ і місцевого самоврядування. Друга причина - недостатність професійних знань і умінь для роботи в умовах демократизації і децентралізації. Третя - «недосконала нормативно-правова база кадрового забезпечення ДКП на регіональному та муніципальному рівнях і відсутність підготовлених професійних кадрів» [3].

Друге коло питань до експертів було пов'язано з виявленням недоліків в роботі з кадрами в ОДВ і ОМС. Експертам потрібно було відповісти на таке запитання: які, на вашу думку, недоліки проявляються в підборі кадрів в ОДВ і місцевого самоврядування? Експертам було запропоновано такі варіанти відповідей (недоліки):

- протекціонізм - заступництво, висунення на посади в ОДВ i OMC за принципом наявності особистої відданості, друзів чи знайомих;

- непотизм - отримання посади в результаті родинних зв'язків, а не професійних здібностей;

- відсутності грунтовних конкурсів щодо заміщення наявних вакантних посад;

- некомпетентність працівників кадрових служб, що займаються питаннями підбору і виховання кадрів в ОДВ і ОМС;

- суб'єктивізм в оцінці ділових і особистісних якостей державних службовців і посадових осіб місцевого самоврядування.

Отримані результати (табл. 8) показують, що головним недоліком при підборі кадрів державних службовців і ПОМС є:

- протекціонізм (заступництво) - 35 \% (підтримка своїх), який впливає і на відсутність конкурсів на заміщення вакантних посад;

- непотизм - 25 \% («кумівство») - отримання посади в ОДВ і ОМС не через особисті професійні якості, здібності, досягнення, а через родинні зв'язки (згідно британського журналу «Тhe 
Economist», Україна входить в першу десятку держав, в яких процвітає кумівство);

- суб'єктивізм - 15 \% в оцінці ділових і особистісних якостей державних службовців і ПОМС;

- некомпетентність працівників кадрових служб (12 \%), котрі здійснюють вирішення питань підбору та виховання кадрів в ОДВ і OMC.

Таблиця 8

\section{Недоліки в підборі кадрів в органах державної влади та місцевого самоврядування [3]}

\begin{tabular}{|c|l|c|}
\hline $\begin{array}{c}\text { № } \\
\text { п\п }\end{array}$ & \multicolumn{1}{|c|}{ Зміст відповідей } & $\begin{array}{c}\text { Процент } \\
\text { відпо- } \\
\text { відей } \\
\text { опитаних } \\
\text { (\%) }\end{array}$ \\
\hline 1. & $\begin{array}{l}\text { Протекціонізм (заступництво), висування на посади в } \\
\text { ОДВ і ОМС за принципом особистої відданості, друзів } \\
\text { або знайомих }\end{array}$ & 35 \\
\hline 2. & $\begin{array}{l}\text { Непотизм («кумівство») - отримання посади в ОДВ і } \\
\text { ОМС через родинні зв'язки }\end{array}$ & 25 \\
\hline 3. & $\begin{array}{l}\text { Суб'єктивізм при оцінці ділових і особистісних якостей } \\
\text { державних службовців і ПОМС }\end{array}$ & 15 \\
\hline 4. & $\begin{array}{l}\text { Некомпетентність працівників кадрових служб, що за- } \\
\text { ймаються питаннями підбору і виховання кадрів в ОДВ } \\
\text { і ОМС }\end{array}$ & 12 \\
\hline 5. & $\begin{array}{l}\text { Відсутність серйозних конкурсів на заміщення вакант- } \\
\text { них посад в ОДВ і ОМС }\end{array}$ & 11 \\
\hline
\end{tabular}

Джерело: Складено авторами на основі даних проведеного опитування серед колишніх службовців ОМС за останні 3 роки.

Вказані «недоліки є «хворобами управління», тому що руйнують довіру, мотивацію в колективі, породжують конфлікти i, як наслідок, неякісне виконання поставлених перед колективом завдань» 
[3]. Крім того вказані «хвороби» призводять до погіршення якісного складу управлінських кадрів ОДВ і ОМС, а точніше, ефективності публічного управління в Україні. Виходячи з вище викладеного, державне управління кадровими процесами на регіональному та муніципальному рівні потребує реформування та вдосконалення. В основу кадрової роботи на регіональному та муніципальному рівнях треба покласти нові кадрові технології, пов'язані з відбором, розстановкою кадрів, їхньою професійною освітою, підвищенням кваліфікації.

Відповідно до результатів опитування, можемо зробити висновок, що основні недоліки щодо підбору непрофесійних кадрів на регіональному та муніципальному рівнях обумовлені відсутністю ефективного кадрового менеджменту, непрофесіоналізмом кадрових служб (управлінь, відділів) використовувати і підбирати кадри, керуючись діловими і моральними критеріями. Зловживаннями в підборі кадрів в ОДВ і ОМС, відсутністю прозорих процедур при проведенні конкурсного відбору.

Таким чином, кадрова політика на регіональному і муніципальному рівнях, можна погодитися В. Федорчук, поки розглядається як «кишеньковий механізм», «кумівство» і «панібратство» в боротьбі за владу $[12$, с. 25]. Тому на роботу в ОДВ і ОМС й потрапляють службовці, які не мають необхідних знань та умінь в області державного та місцевого самоврядування, що призводить до неефективної діяльності ОДВ і ОМС за рішенням складних соціально-політичних і соціально-економічних завдань на регіональному та муніципальному рівнях. Наголосимо, що «запорука успіху всіх реформ, які відбуваються в нашій країні, полягає в тому, щоб в системі державного управління працювали компетентні висококваліфіковані кадри, здатні до творчого вирішення завдань, що стоять перед ними» $[5$, с. 48].

Результати опитування, також підтверджують, що якість діяльності державних службовців та ПОМС на регіональному та муніципальному рівнях залишається досить невисоким, що безпосередньо пов'язано з проблемами ДКП на регіональному та муніципальному рівнях внаслідок: 
- відсутності єдиної ДКП на регіональному та муніципальному рівнях із врахуванням регіональних особливостей;

- недосконалої нормативно-правової бази ДКП, що породжує можливості здійснення численних зловживань під час кадрових призначень;

- низького рівня підготовки кадрових служб в ОДВ і ОМС, які в своїй роботі не використовують досягнення сучасного кадрового менеджменту;

- незадовільні умови роботи, низька оплата праці, перехід досвідчених фахівців в недержавні структури;

- низький рівень професійної підготовки і компетентності державних службовців і ПОМС, непрофільна освіта, низька дисципліна й безвідповідальність.

Розкриваючи проблему ДКП на регіональному та муніципальному рівнях звертаємо увагу, перш за все на те, що іiї стратегія направлена на формування системи роботи з кадрами регіону, громади, але ніяк не пов'язана зі стратегією розвитку регіону, району, громади. Найчастіше вона враховує кількісні, але не якісні характеристиками кадрового забезпечення ОДВ і ОМС кваліфікованими кадрами. На нашу думку головним напрямом ДКП, є регіональний і муніципальний (територіальної громади) рівні, саме в період децентралізації, коли ОМС доводиться вирішувати питання, 3 котрими вони раніше ніколи не стикалися, то очевидними стають факти недостатності управлінського ресурсу.

Висновки. Таким чином, аналіз існуючого стану реалізації ДКП на регіональному та муніципальному рівні дозволяє зробити наступні висновки:

1. Відсутність єдиного концептуального підходу, як до формування, так і реалізації ДКП на регіональному та муніципальному рівнях призводить до того, що в реалізації кадрової політики на регіональному та муніципальному рівнях немає системності, кадрова політика носить фрагментарний, епізодичний характер, іï реалізація віддана на відкуп державним адміністраціям. Тому кадровий потенціал ОМС досить невисокий, такі якості особистості державних службовців і ПОМС, які повинні домінувати (відповідальність 
за результати своєї професійної діяльності, чесність і т.д.) під час виконання ними своїх посадових повноважень, в даний час є незатребуваними. Такий стан потребує суттєвого коригування ДКП на регіональному та муніципальному рівнях.

2. ДКП на регіональному та муніципальному рівні реалізується кадровими службами (управлінь, відділів) і обумовлена наявністю ефективного кадрового менеджменту (системою відбору, розстановки, підвищення кваліфікації, кар'єрного росту, оцінки діяльності кадрів ОДВ і ОМС, наявністю прозорих процедур при проведенні конкурсного відбору) через систему кадрової роботи, основними структурними елементами якої повинні стати:

- аналіз, планування (визначення потреби в кадрах) і прогноз кадрового забезпечення ОДВ і ОМС;

- підбір, розстановка, оцінка (внутрішній моніторинг якості роботи державних службовців і ПОМС) і безперервне навчання кадрів (підготовка, перепідготовка та підвищення кваліфікації);

- управління кадрами повинно здійснюватися не тільки за допомогою економічних організаційно-розпорядчих (нормативно-правових положень), але і соціально-психологічних методів.

3. Стратегія (Концепція) розвитку кадрового потенціалу країни повинна бути складовою соціально-економічного розвитку регіону, громади і передбачати вдосконалення кадрової роботи на регіональному та муніципальному рівнях, через конкретні завдання, поставлені перед кадровими службами для залучення і закріплення в ОДВ і ОМС висококваліфікованих фахівців, створення умов для реалізації ними свого професійного потенціалу, умінь, талантів і здібностей.

\section{Стаття надійшла до редакції: 04.01.20}




\section{PROBLEMS OF PERSONNEL PERSONNEL POLICY AND PROSPECTS OF THE FIRST VIRUSENIA AT THE REGIONAL AND MUNICIPAL RIVERS IN UKRAINE}

Viktoria Andriyash, Doctor of Science in Public Administration, Associate Professor of the Department of Public Administration and Administration Institute of Public Administration Black Sea National University of Petro Mohyla, Mykolaiv, Ukraine

Oleksandr Yevtushenko, Doctor of Political Sciences, Professor, Department of Public Administration and Administration Institute of Public Administration Black Sea National University of Petro Mohyla, Mykolaiv, Ukraine

Sergiy Gonchar, Master of Public Administration Institute of Public Administration Black Sea National University of Petro Mohyla, Mykolaiv, Ukraine

The article has analyzed the special features of the current sovereign cadre policy in the regional and municipal rivals in Ukraine, which is a special system of official business prices, which is governed by the priority principle of administrative regulation. Since the Revolutionaryleadership in the state began to dominate the personnel process, the characteristics of the transitional periods, the nature of non-repetitiveness, the nonlinear nature, the fragmentation of the form of personnel corridor in the central, regional and municipal power supply increased.

It was vouched that the personnel policy became characterized by a high degree of independence and plurality of frames, and the manifestation of greater and greater rewarding of political, rather than business, more than one hour, it was necessary to keep them in good condition that often do not touch the law.

Obviously, without the roguish features of the sovereign cadre policy as a social institution, it is almost impractical for the security service to protect the constitution and the right of service to work and professional development. 
Change your mind to formulate a new paradigm of sovereign cadre policy, like a social institute, oriented to democratic development of the Ukrainian suspension, all the way to the integration course.

It has been established that the sovereign cadre of personnel policy is moving forward not into the tool to fight for moisture, but from the public, but to the enormous resource of public administration of the country.

The special features of the implementation of state power personnel policies in the regional and municipal regions, in the minds of the decentralized states of the state policy for the development of the country, are marked.

At this moment, the development of personnel potential of the country's personnel, the policy is guilty of a warehouse of social and economic development for the region, and for the huge transfer of personnel robots to the regional and municipal districts. It was numbed, with the main impetus of sovereign cadre policy, by the way regional and municipal (territorial) communities, during the decentralized period itself, as long as there was little evidence that the authorities were selfevident.

Keywords: state personnel policy, regional city, municipal city, personnel service

\section{Retrived: 04.01.20}

\section{References}

1. Andriyash V.I., Agafonova N.A. (2017) Vliyanie konflikta na rezultatyi deyatelnosti gosudarstvennoy slujbyi [The impact of the conflict on public service performance] Retrieved from http: http://sci-article.ru/gryps.php?i=politologiya [in Russian]

2. Atamanchuk G.V. (2004), Teoriya gosudarstvennogo upravleniya : kurs lektsiy [Theory of Public Administration: a course of lectures], Omega-L., Moskva. 323 p. [in Russian].

3. Honchar S.V. (2019) Mekhanizmy realizatsii derzhavnoi kadrovoi polityky $\mathrm{v}$ Ukraini na rehionalnomu ta munitsypalnomu rivniakh $\mathrm{v}$ umovakh detsentralizatsii [Mechanisms of implementation of the state personnel policy in 
Ukraine at the regional and municipal levels in the conditions of decentralization]. Retrieved from http: chmnu.edu.ua>uploads 2017/12Disertatsiya_S.V.Gonchar. pdf [in Ukrainian]

4. Hotra V.V., Telychko T.V. (2019), Napriamy vdoskonalennia kadrovoi polityky pidpryiemstva $\mathrm{V}$ suchasnykh umovakh hospodariuvannia [Areas of improvement of personnel policy of the enterprise in modern conditions of management]. "Naukovyi visnyk Uzhhorodskoho universytetu. Seriia "Ekonomika", № 1 (53), pp. 86-90, doi: https://doi.org/10.24144/24096857.2019.1(53).86-90. [in Ukrainian]

5. Denysenko M. P., Budiakova O. Yu. (2019), Pidvyshchennia indeksu liudskoho kapitalu - vazhlyva skladova innovatsiinoi kadrovoi polityky pidpryiemstv [Increasing the human capital index is an important component of enterprise innovation policy]. "Ekonomika ta derzhava", № 4, pp. 11-17, doi: 10.32702/2306-6806.2019.4.11 [in Ukrainian]

6. Kahanovska T. Ye. (2013) Neperervna profesiina osvita kadriv yak odyn $\mathrm{z}$ etapiv prokhodzhennia derzhavnoi sluzhby $\mathrm{v}$ Ukraini [Continuous professional education of the personnel as one of the stages of civil service in Ukraine] "Yevropeiski perspektyvy", № 10, pp. 48-59. [in Ukrainian]

7. Kayl Ya.Ya., Yepinina V.S., Manyakin A.A. (2013), Problemy kadrovogo obespecheniya organov mestnogo samoupravleniya i puti ikh resheniya (na primere makroregiona YuFO) [Problems of staffing of local governments and their solutions (for example, the macroregion of the Southern Federal District)], "Regionalnaya ekonomika. Yug Rossii”, № 2 (2), pp. 216224. [in Ukrainian]

8. Kibanov A.Ya., Konovalova V.G., Ushakova M.V. (2010), Sluzhba upravleniya personalom: ucheb. posobie [Service personnel management: studies. allowance]. Knorus, Moskva. [in Russian]

9. Mamonova V. V. (2011), Systema mistsevoho samovriaduvannia [The system of local self-government], Entsyklopediia derzhavnoho upravlinnia u 8-my t. / Natsionalna akademiia derzhavnoho upravlinnia pry Prezydentovi Ukrainy; nauk.-red. kolehiia: Yu. V. Kovbasiuk (holova) ta in. NADU, Kyiv, T. 5, pp. 342-344. [in Ukrainian]

10. Moll Ye.G. (2011), Upravlenie kareroy menedzhera [Manager career management]. Izdatelskiy dom "Piter", Sankt Peterburg, 424 p. [in Russian]

11. Ogloblina I.Ye. (2011), Uchebnoe posobie po distsipline "Kadrovaya politika organov regionalnogo upravleniya". [Utorial for the discipline «Personnel policy of regional authorities»] Alt.gos.tekhn.un-t im. I.I. Polzunova. Izd-vo AltGTU, Barnaul, 362 p. [in Russian] 
12. Pashko L. (2011), Profesiina osvita derzhavnykh sluzhbovtsiv ta posadovykh osib mistsevoho samovriaduvannia: akmeolohichnyi pidkhid [Professional education of civil servants and officials of local self-government: acmeological approach], "Visnyk Natsionalnoi akademii derzhavnoho upravlinnia”, № 3, pp. 77-84. [in Ukrainian]

13. Fedorchuk V.A. (2015), Orhanizatsiino-pravove zabezpechennia kadrovoi polityky v derzhavnomu upravlinni [Organizational and legal support of personnel policy in public administration], "Visnyk NADU”, № 1, pp. 23-29. [in Ukrainian]

14. Yemelianov V.M., Verba S.M. (2010) Kadrove zabezpechennia orhaniv derzhavnoi vlady ta mistsevoho samovriaduvannia v Mykolaivskii oblasti [Staffing of state authorities and local self-government in the Mykolaiv region] Naukovi pratsi: Naukovo-metodychnyi zhurnal. T. 147. Vyp.135 pp. 60-65. [in Ukrainian]

\section{Відомості про авторів / Information about the Authors}

Андріяш Вікторія Іванівна: Інститут державного управління, Чорноморський національний університет імені Петра Могили вул. 68 десантників 10, Миколаїв, 54003, Україна.

Victoria Andriyash: Institute of Public Administration Black Sea National University of Petro Mohyla: 68 Desantnykiv str. 10, Mykolaiv, 54003, Ukraine.

\section{ORCID. ORG/0000-0001-5294-7456}

\section{E-mail: andriyash_v2017@ukr.net}

Свтушенко Олександр Никифорович: Чорноморський національний університет імені Петра Могили: вул. 68 десантників 10, м. Миколаїв, 54003, Україна.

Alexander Evtushenko: Institute of Public Administration Black Sea National University of Petro Mohyla: 68 Desantnykiv str. 10, Mykolaiv, 54003, Ukraine. 
«Public Administration and Regional Development»

https://pard.mk.ua/index.php/journal

ORCID.ORG/ 0000-0002-5161-3312

\section{E-mail: alnievt@ukr.net}

Гончар Сергій Володимирович: Військова частина № 9997: вул. Д.Інглезі буд. 9/2, м. Одеса, 65070, Україна.

Sergiy Gonchar: Military Unit № 9997: D. Englezi str. 9/2, Odesa, 65070, Ukraine.

E-mail: sergeygonchar1964@gmail.com

ORCID.ORG/0000-0002-6172-7987 